ROCZNIKI NAUK PRAWNYCH

Volume XXVIII, number 3-2018

Eng $1 \mathrm{is} \mathrm{h}$ ve r s i o n

DOI: http://dx.doi.org/10.18290/rnp.2018.28.3-6en

KRZYSZTOF ŁOPUSZYŃSKI

\title{
THE IDEA OF CENTRAL BANKING IN THE FINAL YEARS OF THE FIRST POLISH REPUBLIC
}

\section{INTRODUCTION}

The history of central banking in Poland dates back nearly 200 years. From 1828 to 1886, the first issuing institution called Bank Polski operated in the Kingdom of Poland. It was a state bank, funded by the government, which issued the Polish złoty notes and serviced public debt as well as conducting credit activity. Although the history of the Polish central banking system took on a real shape during the partition era, the idea of creating a central bank in the Polish Republic - a bank understood as the national, issuing bank with a commercial character-was born in the final years of the First Republic. ${ }^{1}$ The idea sprang mainly from the need for a change in Poland's monetary system seen by the contemporaries. The lack of bullion money in circulation was felt, which was to be replaced with the so-called bilet bankowy [bank note-Translator's note]. The task of issuing paper money was to be carried out by the state bank.

This publication presents the conception of creating a national bank, which was the subject of discussion of the elite of that time. At the end of the eighteenth century, the debate yielded numerous plans, which due to the collapse of the Polish state were never put into practice. ${ }^{2}$

KRZYSZTOF ŁOPUSZYŃSKI, MA, is a doctoral student and the Department of History of State and Law, Institute of Law, Faculty of Law, Canon Law and Administration of the John Paul II Catholic University of Lublin (KUL); address: Racławickie 14, 20-950 Lublin, Poland; e-mail: klopuszynski@student.kul.lublin.pl; https://orcid.org/0000-0002-5871-2305.

${ }^{1}$ C. LESZCZYŃSKA, Zarys historii polskiej bankowości centralnej (Warszawa: Narodowy Bank Polski, 2010), 7.

${ }^{2}$ T.J. Buczkowski writes about different plans of issuing banknotes in BUCZKOwSKI, "Pieniądz i kredyt w okresie rozbiorów," in Bank Polski 1828-1928 dla upamiętnienia stuletniego jubileuszu otwarcia, by T.J. BuczKowsKi and H. NowaK, 20-21 (Warszawa: Drukarnia Banku 


\section{BANKING ACTIVITY \\ IN THE POLISH-LITHUANIAN COMMONWEALTH}

Since the Middle Ages, banking activity in Poland had been conducted by families of merchants who owned banking houses, which often supported kings in their various enterprises. The most prominent representatives were: Mikołaj Wierzynek and Hańko Kępicz during the reign of Casimir III the Great, the Morsztyn and Szwarc families during the reign of Władysław Jagiełło, the Betman, Boner and Montelupi families during the reign of Kings Sigismunds. Jewish bankers came to prominence, notably Lewko, Wołczek and Abraham Ezofowicz. Other well-known banking representatives included Robert Forbes, a royal secretary, and Jerzy Hawel, who supported the maritime policy of King Władysław IV Vasa.

Besides merchants, in the times of the Polish-Lithuanian Commonwealth, the lending activity was also conducted by mounts of piety (bank poboziny). The first of these in Poland were founded by Piotr Skarga: in 1579 in Vilnius, in 1587 in Kraków, and in 1589 in Warsaw. By the middle of the $17^{\text {th }}$ century, there were already a dozen or so such banks operating. Mounts of piety granted small consumer loans secured by movable property, initially interest-free, then at low interest rates. They were an element of the Church's campaign against usury. In the 18th century, banking houses established in Warsaw played an increasingly important role. Since the Saxon times, banking activity had evolved, becoming gradually separate from merchant activity. The most important bankers of this period are: Adam Zimman, Piotr Riaucour, the Tepper family. Many of them were ennobled. ${ }^{3}$ Among the magnates, banking activity was pursued by Antoni Protazy Potocki, known mainly for his Black Sea Trade Company, who supported the exports of Polish goods across the Black Sea to French and Italian ports. ${ }^{4}$

Polskiego, 1928), 20-21. This subject matter is also discussed in M. SosNOwsKA-ŁozIŃSKA, “Geneza, powstanie i działalność Banku Polskiego w latach 1828-1885," Zeszyty Naukowe Uniwersytetu Rzeszowskiego. Seria Prawnicza 53 (2009): 179-84.

${ }^{3}$ One of the most significant ennoblements was conferred by the Four-Year Sejm in 1790, and it covered six "bigger" bankers: Peter Tepper of the Ferguson family (Younger), Karol Szulc, August Wilhelm Arndt, Frederick Kabrit, Jan Meysner, and Piotr Blanc, see I. Kras, "Ewolucja polskiego systemu bankowego," Saeculum Christianum: pismo historyczno-spoteczne 13, no. 2 (2006): 187; W. MORAWSKI, Stownik historyczny bankowości polskiej do 1939 roku (Warszawa: Wydawnictwo "Muza," 1998), 9-10.

${ }^{4}$ W. MoRAwski, Historia bankowości na ziemiach polskich. Od Piotra Skargi do Andrzeja Kapostasa, accessed April 18, 2017, http://mowiawieki.pl/templates/site_pic/files/HistoriaBankowosci NaZiemiachPolskich_01. pdf. 


\section{PROPOSALS FOR THE CREATION OF A NATIONAL BANK}

The need for a public bank in the Polish State came to be discussed in the latter half of the eighteenth century by the most eminent minds. Reasons for those disputes were varied. The basic argument was that the State Treasury and monetary affairs had to be put in order. The establishment of a national bank was supposed to be a way to increase the State's revenue. Another factor encouraging reforms in this regard was the functioning of the private banking sector. Reformists writing about the necessity of creating a national bank sought to limit the profits of bankers getting richer not only from their own commercial activity but also from loans they granted to the State or by acting as mediators in the arrangement of such, also abroad. ${ }^{5}$ The need to have a public, or state-owned bank became visible. The existence of such an institution would be an attempt to make the Polish Republic independent from the neighbouring powers, which were effectively putting shackles on the Polish economy. ${ }^{6}$ The international context was also important, with central banks existing in countries like Sweden (Sveriges Riksbank-1668), England (Bank of England-1694), and the Netherlands to support the monetary systems of those states. ${ }^{7}$

The first representative to write about the necessity of establishing a public bank in Poland was Stanisław Konarski. In the fourth volume of O skutecznym rad sposobie (1763), he proposed that the capital of the na-

\footnotetext{
${ }^{5}$ Ku pożytku dobra wspólnego. Historia pieniądza, finansów i bankowości spótdzielczej, ed. A. Bochen (Bydgoszcz: Quixi Media, 2015), 79. C. LeszczyńsKA, "Polska bankowość centralna 1828-1989 Bank Polski, Polska Krajowa Kasa Pożyczkowa, Bank Polski S.A., Narodowy Bank Polski," in Bankowość centralna od A do Z, ed. R. Kokoszczyński and B. Pietrzak (Warszawa: Narodowy Bank Polski, 2007), 29.

${ }^{6}$ For example, the activity of neighbouring Prussia consisting in flooding the Polish market with counterfeit money. This problem also was noticed by the nobility, who called for fair "minting of coins" and supervision of the State mint during sejmiks [regional assembliesTranslator's note] debates (see Lauda sejmikowe województwa lubelskiego, Obb. Gr. Lub. S.374 t. 682, A.D. 1764). The interest of enlightened citizens in the ideas of central banking grew in the wake of the First Partition of Poland, when the state lost about $30 \%$ of its territory and its international position deteriorated significantly. See A. JEZIERSKI and C. LESZCZYŃSKA, Historia gospodarcza Polski (Warszawa: Wydawnictwo Key Text, 1998), 67, 97.

${ }^{7}$ The reasons for the creation of central banks in Europe were linked to the need to tidy up the monetary system of these countries, which was disrupted by the activity of commercial banks issuing depositary receipts in exchange for bullion or coins. Excessive and issue of uncovered banknotes, despite its positive impact at first, led to banks becoming insolvent, which paved the way for economic crisis and undermined public confidence in banks. See E. KosIERADZKA, "Geneza banku centralnego na ziemiach polskich," Annales Universitatis Mariae Curie-Skłodowska Lublin-Polonia. Sectio G (Ius) 63, no. 1 (2016): 42.
} 
tional bank should come from the sale of national property. As a result, "the sums collected from them would be a large fund for the Bank of Poland." $\mathrm{He}$ did not specify the bank's rules of operation; he merely invoked the "English, Dutch, Swedish etc." models. ${ }^{8}$

From that period comes a brochure by an unknown author, entitled O Banku Narodowym tatwo ustanowić się mogacym [On the National Bank which is easy to establish]. The funds of the newly established bank were to come from the sale of starostwos [county-like administrative unit-Translator's note]. The bank would be state-owned, based on the lending and deposit-taking activity. ${ }^{9}$

The ideas about the bank's issue activity were different. In 1774, a project of an unknown author appeared with a proposal to create a "paper coin" in the form of covered bonds of land credit societies. In 1789, Michał Ossowski published a study entitled $O$ pomnożeniu dochodów publicznych, wynalezieniu kapitału publicznego ku zasileniu nowych potrzeb Rzeczypospolitej z oszczedzeniem podatków [On multiplying public income and finding public capital to meet the new demands of the Polish Republic and saving taxes]. According to this author, the national bank would issue treasury notes (up to 20 million Polish złoty) through the Crown Treasury Commission. The issue would be backed by State property and their sale would lead to a gradual redemption of the notes. In his work entitled Projekt Banku Narodowego [A design for the National Bank] (1790), Jacek Jezierski, the castellan of Łuków, envisaged a national bank established for a period of 20 years, issuing paper money up to the worth of 80 million złotys, where half of the public expenditure would be covered by banknotes. Banknote holders could exchange them for bullion at the bank's cash desks. In addition, there would be a pawn shop offering loans at $7 \%$ against bullion, jewels or real estate. Another representative, Karol Glave, in his work entitled Układ ogólny dwóch Banków dla Rzeczypospolitej, jednego na dobra ziemskie a drugiego na dobra ruchome [A general system of two banks for the Polish Republic, one for landed estate and the other for movable assets" (ca. 1790) envisaged the bank as a state-owned company ( $1 / 3$ share) with a 40 -year privilege of issuing money. In exchange for this privilege, the State would receive a $6 \%$ loan. ${ }^{10}$

\footnotetext{
${ }^{8}$ S. KONARSKI, O Skutecznym Rad Sposobie Albo O Utrzymywaniu Ordynaryinych Seymow. Cz. 4 Y Ostatnia ( Warszawa: w Drukarni J.K. Mci y Rzplitey u XX. Sebolarum Piarum, 1763), 301, Jagiellonian Library, ref. Berol. Ud 6452.

${ }^{9}$ LesZCZYŃSKa, Zarys Polskiej, 7.

${ }^{10}$ T. Korzon, Wewnętrzne dzieje Polski za Stanistawa Augusta 1764-1794 (Kraków: Księgarnia L. Zwolińskiego i Spółki, 1884) 3: 306-315.
} 
One of the most notable promoters of central banking was Jędrzej Kapostas (1757-1796) - a Warsaw banker of Hungarian origin, a prominent patriot and the author of a design for a national bank. The first detailed biographical information about Kapostas comes from the time when he settled in Poland in 1780 . He was a very well-educated man, not only in economics but also in languages. He published several political-economic studies. The most famous of them are: $O$ banku narodowym $w$ Polszcze ustanowić się majacym [On a national bank to be established in Poland] (1789) and Planta utożenia projektu Banku Narodowego [A plan of the organisation of the National Bank] (1790). In 1790, he was conferred the Odrowąż coat of arms. He took an active part in the preparation of the Kościuszko Uprising. After the fall of the uprising he was arrested in December 1794 and imprisoned in a Petropavlovsk fortress (Russia), where he spent two years. He died shortly after his release.

Jędrzej Kapostas saw the reasons for setting up issuing banks in Europe in the insufficiency of capital. In this way, banks themselves could become a source of capital by issuing it. His plan envisaged a Polish bank which was to be created with funds from the sale of national assets and its activity was to involve issuance of "bank assignments" (bank notes). Its duration was set at 20 years with the right to issue bank assignments in notes of 10, 25, 50, 100, 500, and 1000 Polish złotys, in a total amount of 40 million Polish złotys. The entry of bank assignments into circulation would be strengthened by a decree of the Sejm prescribing that "all kinds of public taxes be paid half in such Notes and half in Cash [...] because it would be difficult to dissuade a citizen from accepting the notes if he did not know that he every tax would require such notes." 11 The issue was to be controlled by the Banking Commission. The exchange rate for the notes would be fixed, and the issue of assignments would be one of the sources of income for the State Treasury. Kapostas believed that part of this income could be used for commercial operation - the establishment of a bank granting long-term loans, together with private shareholders, a pawn institution with the right to issue its own notes (up to 40 million Polish złoty), and a commercial credit bank. The issue

11 “wszelkie podatki publiczne połowę w takowych Biletach, a połowę w Gotowiźnie opłacać [...] bo trudnoby obywatelowi wyperswadować można było przyjmowanie biletów, pókiby on nie wiedział, że koniecznie, przy każdym podatku, takowych biletów potrzebować będzie," A. KAPOSTAS, Planta ułozenia projektu banku narodowego do przeswietney Deputacyi Projektu Ekonomiki Krajowey ( Warszawa: w Drukarni Nowey J.K.Mci Rzpltey u Piotra Zawadzkiego, 1790), 4, National Library, ref. SD XVIII 3.5992. 
would be secured in at least 50 per cent by cash, mortgage on the shareholders' property, and government guarantees. ${ }^{12}$

Kapostas' work was criticized. Noble Sejm deputies noticed that the issue of paper assignments would give rise to public debt, considered a "disaster." The "general harmfulness of paper money" was emphasised. In Kazimierz Konstanty Plater's work entitled O Bank Narodowym w Polszcze ustanowić sie tatwo mogacym [On the National Bank in Poland which is easy to establish] (1789), it was pointed out that there was a shortage of precious metals in Poland, therefore the Kapostas' plan involving the issue of "millions of paper notes" had no chance implementation. It was feared that the unsuccessful experiment that took place in France at the beginning of the $18^{\text {th }}$ century would be repeated. ${ }^{13}$

\section{PLANS FOR THE CREATION OF A NATIONAL BANK}

During the reign of King Stanisław, there were attempts to put the idea of creating a national bank into practice. In 1774, the first proposal was presented to the King by August Sulkowski, the voivode of Gniezno. It consisted in "multiplying the Republic's income by the establishment of a Bank that would pay a commission in the manner indicated in the proposal." However, it was not reviewed. ${ }^{14}$ The successive proposals which were not addressed were submitted to the Permanent Council. The first of them, by banker Ziemann (1776), called for the creation of a pawn shop in Warsaw. The proposal was referred to the Police Commission and then rejected. ${ }^{15}$ A year later, a proposal by a nameless author was received, which also envisaged the creation of a bank, and the missing funds were to be covered

\footnotetext{
${ }^{12}$ LESZCZYŃSKA, Zarys historii, 7.

${ }^{13}$ The lack of control over the issue of paper banknotes led to many cases of bankruptcy. One of the best known cases was the collapse of John Law's Bank, established in France in 1716. The bank granted loans to the State for the service of national debt using funds acquired from share issue. However, the operations were very risky. Over time, the proportion between the value of the banknotes issued and the amount of silver and gold available for exchange became significantly shaken. Finally, there were no means to cover the notes with bullion, which led to the bankruptcy of the bank in 1720. See LESZCZYŃSKA, Zarys historii, 8.

${ }^{14}$ S. KARPIŃSKI, Zasady działalności banków $i$ zarys historyczny głównych epok ich rozwoju (Warszawa: E. Wende i Sp., 1898), 99.

${ }^{15}$ Buczkowski, Pieniądz i kredyt, 20.
} 
by a "paper coin based on land."16 In the years 1780 and 1786, proposals for the establishment of the National Bank were submitted to the Sejms, but they were not part of the agenda. ${ }^{17}$ In 1786 , the King put forward a proposal for the creation of the bank. It included a request to appoint "persons to ponder plans of banks, pawnshops, insurance institutions and that, after due consideration, one proposal be created." However, no committee was created as proposed by the King, despite the support of several deputies. ${ }^{18}$ Despite those setbacks, the interest in establishing a bank was growing, as shown by the activity of Rev. Piotr Świtkowski, who reported on the current functioning of foreign banks in the magazine "Pamiętnik Historyczny i Polityczny." In 1790, he submitted a proposal for the establishment of a bank of issue. ${ }^{19}$

Proposals to create a national bank were presented during the sessions of the Grand Sejm. The first of them, put forward by Rev. Michał Ossowski in 1789 , provided for the creation of capital stock from public property, including the royal estate and the estate of starosts and vogts. This property was to be transformed into a inheritable land property and by the time the operation was complete, treasury note ${ }^{20}$ had to be issued. Initially, the Sejm created a commission of deputies "to create a proposal of domestic economy," which was to consider it. However, we do not have any traces of its activities. The question of issuing paper money received more serious consideration only when funds for the completion of an army of 100,000 were being sought. The proposal of Rev. Ossowski, despite enjoying the support of many deputies, was never debated because the idea of selling the national assets was not popular. ${ }^{21}$ Only when threatened by a war with Russia in 1791

\footnotetext{
${ }^{16}$ C. Łagiewski, "Bankierstwo w dawnej Polsce i w epoce stanisławowskiej," in Dzieje gospodarcze Polski porozbiorowej w zarysie, ed. S.A. Kempner (Warszawa: Druk K. Kowalewskiego, 1920), 68.

${ }^{17}$ A. GRoDek, Idea Banku Narodowego (Geneza Banku Polskiego 1763-1828) (Warszawa: Szkoła Główna Handlowa, 1936), 17.

${ }^{18}$ These were, among others, Jan Zyberk and Władysław Guzowski, see Zbior Mów, Głosów, Przymówien, Manifestów, Remanifestów, \&c. Mianych Na Seymie Roku 1786 (Warszawa: w drukarni P. Dufour, 1787), 1:464, 2:473, Jagiellonian Library, ref. BJ St. Dr. 17974 I; quoted after GRODEK, Idea Banku, 20.

${ }^{19}$ GrodeK, Idea Banku, 20-21.

${ }^{20}$ The author estimated the value of public property at about 300 million złoty. He was aware of the difficulty selling vast stretches of landed property, so he suggested issuing treasury notes worth 18-20 million złoty and redeeming them within 10-12 years using proceeds from the sale; see BuCZKOwsKi and NowaK, Bank Polski 1828-1928, 22. Treasury notes were similar to assignments functioning in parallel during the French Revolution.

${ }^{21}$ On the activity of parties presenting programmes of healing the Polish Treasury through the reform of the royal lands and the creation of a national bank, see A. STROYNOWSKI, "Kształtowanie
} 
did the Sejm consider the first part of the project concerning the sale of royal estate, but it rejected the second part envisaging the issue of treasury notes. ${ }^{22}$

In 1790, Jędrzej Kapostas presented to the Sejm "Planta ułożenia projektu Banku Narodowego [A plan of the organisation of the National Bank]." The plan was elaborated in detail and included explanations so that it could be legislated soon. Despite the favourable reception of some deputies, particularly Jacek Jezierski, the Castellan of Łuków, the Sejm, preoccupied with other political matters, excluded the proposal from becoming part of the agenda. ${ }^{23} \mathrm{~A}$ similar situation was observed in the case of other proposals submitted successively to the Marshal (the last one was in the Sejm files of 1792). ${ }^{24}$

\section{ISSUE OF THE FIRST PAPER MONEY}

The first paper money was issued during the Kościuszko Uprising. The main reason for this was the need to finance the uprising, expenses which could not be covered using traditional funding. Not without significance was the careful monitoring of monetary issues and the way they were resolved during the French Revolution, as well as the personal experience of Tadeusz Kościuszko from his time of fighting in the American war of independence. On June 8, 1794, the insurgent government-the Supreme National Council-established the Treasury Notes Administration-the first institution of issue in the history of Poland, and adopted a resolution on the issue of paper money with face values: 5, 10, 25, 50, 100, 500, and 1000 złoty in the total amount of 60 million złoty. The value of treasury notes was made equal to

się stronnictwa republikańsko-kołłątajowskiego w Sejmie Czteroletnim w toku walki o reformę królewszczyzn," Acta Universitatis Lodziensis. Folia Historica 3 (1981): 3-25.

${ }^{22}$ KosieradzKa, Geneza banku, 46; GrodeK, Idea Banku, 17.

${ }^{23}$ The nobility of Lublin, represented by Jacek Jezierski, put forward a proposal to enlarge the Treasury Commission with representatives of the bourgeoisie. They were also to be "used for the establishment of the National Bank," see Instrukcja sejmikowa uchwalona na zgromadzeniu szlachty lubelskiej $w$ dniach 16-19 listopada 1790 roku postom na sejm, KGL, RMO, APL, ref. 512, sheet 548, copy TP, signature 8326, pp. 483-97.

${ }^{24}$ These include, in particular, the following works: by Kazimierz Konstanty Plater, entitled O banku narodowym w Polsce ustanowić się tatwo mogacym (1789); by Jezierski, entitled Projekt Banku Narodowego (1790); by Glave and other unknown authors, entitled Układ ogólny dwóch Banków dla Rzeczypospolitej, jednego na dobra ziemskie a drugiego na dobra ruchome (ca. 1790); Bank Krajowy, projekt do prawa na 4-letni Sejm (1790) and Projekt na Bank Nacyonalny, found among the papers of Sejm Marschal Małachowski. See BuCZKOwSKI and NowAK, Bank Polski, 21; A. StolarsKa, Bankowość centralna w Polsce. Lata 1828-1989 (Lublin: Wydawnictwo Werset, 2016), 32. 
that of bullion coins, and payments were made at an imposed rate. Liabilities towards the state were to be settled half in coins and half in assignments. This led to some reluctance to accept paper money, therefore the Supreme National Council changed its decision on 29 September 1794 allowing obligations to be accepted in treasury notes in whole. ${ }^{25}$ Despite these efforts, about 10 million Polish złotys were issued, which after the collapse of the uprising ceased to be legal tender, which strengthened the public's reluctance to pay paper money. ${ }^{26}$

\section{THE LEGACY OF $18^{\text {TH }}$-CENTURY WRITERS IN THE FIRST BANK OF POLAND}

With the fall of the Polish Republic caused by the Third Partition of Poland in 1795, discussions on the establishment of a national bank were interrupted. They were resumed after the Duchy of Warsaw and then the Kingdom of Poland were established in 1815. Compared to the last years of the Polish Republic, the debate did not take place in the Sejm, but in the political elite circles of the time. Such figures as Stanisław Staszic, Fryderyk Skarbek, Ksawery Drucki-Lubecki, Kajetan Kalinowski, Józef Zajączek and others addressed this subject. ${ }^{27}$ The political and economic situation had changed radically. Despite its broad political and economic autonomy, the newly formed state organism remained dependent on Russia. The economy was destroyed by the Napoleonic Wars and required reconstruction. It was done by the Minister of Revenue and Treasury, Prince Ksawery DruckiLubecki, who first established the Land Credit Society in 1825 to support agriculture with mortgage loans and then established the issuing and lending Bank of Poland in 1828. The first ever Polish central bank was a phenomenon on a European scale because it was characterised by a universal activity consisting not only in issuing money but also in granting working capital

\footnotetext{
${ }^{25}$ L. KокосIŃSKI, Pieniądz papierowy na ziemiach polskich (Warszawa: Rosikon Press, 1996), 13-14.

${ }^{26}$ Different amounts of the paper money issued are reported. Jezierski and Leszczyńska mention 8 million, while Kokosiński quotes the exact amount—including substitute notes (bilety zdawkowe) - as 10,886,751 Polish złoty, see: JEZIERSKI and LESZCZYŃSKA, Historia, 98; KoKOCIŃSKI, Pieniądz papierowy, 14.

${ }^{27}$ A. Jezierski and C. Leszczyńska, Bank Polski SA 1924-1951 (Warszawa: Narodowy Bank Polski, 1994), 11.
} 
loans and investment loans, whereas the central banks at that time focused on issuing money and granting loans, excluding long-term loans.

\section{CONCLUSION}

The idea of creating a national bank in Poland grew stronger in the second half of the eighteenth century. It was influenced by the activity of Enlightenment authors who saw problems of banking; likewise, they observed the experience of other countries implementing reforms in this area, especially England and revolutionary France. Initially, the idea was disseminated in brochures, essays and other works of a social and economic nature. Over time, however, it took the form of proposals submitted initially to the Permanent Council and finally to the Sejm. Most ideas were put forward by the members of the Four-Year Sejm. Due to the tense international situation and the imminent collapse of the Polish state, none of them was put into practice. However, the presented proposals spurred discussion in the new political environment after the establishment of the Kingdom of Poland and laid the foundations for the establishment of the Bank of Poland.

\section{BIBLIOGRAPHY}

ARCHIVAL SOURCES

State Archive in Lublin. Księgi Grodzkie Lubelskie Relacje, Manifesty, Oblaty: 374 A.D. 1764. 512 copy by TP, ref. 8326 A.D. 1790.

Kapostas, Andrzej. Planta ułożenia projektu banku narodowego do prześwietney Deputacyi Projektu Ekonomiki Krajowey. Warsaw: w Drukarni Nowey J.K.Mci Rzpltey u Piotra Zawadzkiego, 1790; National Library, ref. SD XVIII 3.5992.

KonARSki, Stanisław. O Skutecznym Rad Sposobie Albo O Utrzymywaniu Ordynaryinych Seymow. Cz. 4 Y Ostatnia. Warszawa: w Drukarni J.K. Mci y Rzplitey u XX. Sebolarum Piarum, 1763; Jagiellonian Library, ref. Berol. Ud 6452.

Zbior Mów, Gtosów, Przymówien, Manifestów, Remanifestów, \&c. Mianych Na Seymie Roku 1786. Vols. 1-2. Warsaw: w drukarni P. Dufour, 1787; Jagiellonian Library, ref. BJ St. Dr. $17974 \mathrm{I}$.

\section{LITERATURE}

Buczkowski, Tomasz J., and Henryk NowAK. Bank Polski 1828-1928 dla upamiętnienia stuletniego jubileuszu otwarcia. Warszawa: Drukarnia Banku Polskiego, 1928. 
BuczKowski, Tomasz J. "Pieniądz i kredyt w okresie rozbiorów." In Bank Polski 1828-1928 dla upamiętnienia stuletniego jubileuszu otwarcia, by Tomasz J. BUCZKOwsKI and Henryk NowaK, 3-30. Warszawa: Drukarnia Banku Polskiego, 1928.

GrodeK, Andrzej. Idea Banku Narodowego (Geneza Banku Polskiego 1763-1828). Warszawa: Szkoła Główna Handlowa, 1936.

JeZIERski, Andrzej, and Cecylia LeszCZyŃska. Bank Polski SA 1924-1951. Warszawa: Narodowy Bank Polski, 1994.

JEZIERSKI, Andrzej, and Cecylia LeSZCZYŃSKA. Historia gospodarcza Polski Warszawa: Wydawnictwo Key Text, 2001.

KARPIŃSKI, Stanisław. Zasady działalności banków i zarys historyczny głównych epok ich rozwoju. Warszawa: E. Wende i Sp., 1898.

KoKOciŃSKI, Lech. Pieniądz papierowy na ziemiach polskich. Warszawa: Rosikon Press, 1996.

Korzon, Tadeusz. Wewnętrzne dzieje Polski za Stanistawa Augusta 1764-1794. Vol. 3. Kraków: Księgarnia L. Zwolińskiego i Spółki, 1884.

KosieradzKA, Eliza. "Geneza banku centralnego na ziemiach polskich." Annales Universitatis Mariae Curie-Skłodowska Lublin-Polonia, Sectio G (Ius) 63, no. 1 (2016): 41-60.

Kras, Ireneusz. "Ewolucja polskiego systemu bankowego." Saeculum Christianum: pismo historyczno-społeczne 13, no. 2 (2006): 187-214.

Ku pożytku dobra wspólnego. Historia pieniadza, finansów i bankowości spółdzielczej, edited by Antoni Bochen. Bydgoszcz: Quixi Media, 2015.

LesZCZyŃskA, Cecylia. "Polska bankowość centralna 1828-1989 Bank Polski, Polska Krajowa Kasa Pożyczkowa, Bank Polski S.A., Narodowy Bank Polski." In Bankowość centralna od A do Z, edited by Ryszard Kokoszczyński and Bogusław Pietrzak, 27-64. Warszawa: Narodowy Bank Polski, 2007.

LESZCZYŃSKA, Cecylia. Zarys historii polskiej bankowości centralnej. Warszawa: Wydawnictwo Narodowy Bank Polski, 2010.

ŁAGIEwski, Cezary. "Bankierstwo w dawnej Polsce i w epoce stanisławowskiej." In Dzieje gospodarcze Polski porozbiorowej w zarysie, edited by Stanisław Aleksander Kempner, 1: 5768. Warszawa: Druk K. Kowalewskiego, 1920.

MoRAWSKI, Wojciech. Historia bankowości na ziemiach polskich. Od Piotra Skargi do Andrzeja Kapostasa. Accessed April 4, 2017. http://mowiawieki.pl/templates/site_pic/ files/HistoriaBankowosciNaZiemiachPolskich_01.pdf.

MORAWSKI, Wojciech. Stownik historyczny bankowości polskiej do 1939 roku. Warszawa: Wydawnictwo "Muza," 1998.

SosnowsKA-ŁoziŃSKA, Magdalena. "Geneza, powstanie i działalność Banku Polskiego w latach 1828-1885.” Zeszyty Naukowe Uniwersytetu Rzeszowskiego. Seria Prawnicza 53 (2009): 179-196.

Stolarska, Agnieszka. Bankowość centralna w Polsce. Lata 1828-1989. Lublin: Wydawnictwo Werset, 2016.

STROYNOwSKI, Andrzej. "Kształtowanie się stronnictwa republikańsko-kołłątajowskiego w Sejmie Czteroletnim w toku walki o reformę królewszczyzn." Acta Universitatis Lodziensis. Folia Historica 3 (1981): 3-25. 


\section{THE IDEA OF CENTRAL BANKING IN THE FINAL YEARS OF THE FIRST POLISH REPUBLIC}

\section{Summary}

The need to establish a national bank in the Polish Republic was addressed in 1763 by $\mathrm{Fr}$ Stanisław Konarski in his $O$ skutecznym rad sposobie. The need to secure the issue of Polish money increased as a result of the crisis caused by the flooding of the Polish market with Polish coins counterfeited in Prussia. The discussion was joined by proponents of mercantilism, who saw the possibility of keeping good Polish money in circulation by using dead capital in "deposit coffers." However, only the Sejm could establish a central bank. The first drafts saw the light during the sessions of the Four-Year Sejm (1788-1792). Among them, the proposal of the famous Warsaw banker Jędrzej Kapostas deserves our attention, who in 1789 published a work entitled $O$ banku narodowym w Polszcze and Planta ułożenia projektu Banku Narodowego in the next year. Paper money in Poland appeared in circulation during the Kościuszko Uprising. To this end, the Treasury Notes Administration was established, which issued so-called "assignments." They survived until the fall of the uprising. The Third Partition of Poland put an end to the discussion of the establishment of a central bank.

Key words: history of banking; central bank; Four-year Sejm; paper money; bankers.

Translated by Tomasz Patkowski

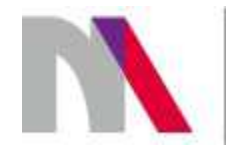

The preparation of the English version of Roczniki Nauk Prawnych (Annals of Iuridical Sciences) and its publication in electronic databases was financed under contract no. 836/PDUN/2018 from the resources of the Minister of Science and Higher Education for the popularization of science. 